\title{
Similarities between recent seismic activity and paleoseismites during the late miocene in the external Betic Chain (Spain): relationship by ' $b$ ' value and the fractal dimension
}

\author{
M.A. Rodríguez Pascua ${ }^{\mathrm{a}, *}$, G. De Vicente ${ }^{\mathrm{b}}$, J.P. Calvo ${ }^{\mathrm{c}}$, R. Pérez-López ${ }^{\mathrm{b}, \mathrm{d}}$ \\ ${ }^{a}$ Dpto. Ciencias Ambientales y Recursos Naturales. F. CC. Experimentales y de la Salud, Univ. San Pablo-CEU, 28668 Boadilla del Monte, Madrid, Spain \\ ${ }^{\mathrm{b}}$ Dpto. Geodinámica, F.CC. Geológicas, Univ. Complutense, 28040 Madrid, Spain \\ ${ }^{c}$ Dpto. Petrol. y Geoquím., F.CC. Geológicas, Univ. Complutense, 28040 Madrid, Spain \\ ${ }^{\mathrm{d}}$ EOST-Institut de Physique du Globe, Université Louis Pasteur. 5/ Rue Rene Descartes, 67084. Strasbourg, France
}

\begin{abstract}
A paleoseismic data set derived from the relationship between the thickness of seismites, 'mixed layers' in lacustrine Miocene deposits and the magnitude of the earthquakes is presented. The relationship between both parameters was calibrated by the threshold of fluidification limits in the interval of magnitude 5 and 5.5. The mixed layers (deformational sediment structures due to seismic activity) were observed in varved sediments from three Neogene lacustrine basins near Hellín (Albacete, Spain), El Cenajo, Elche de la Sierra and Híjar, and are interpreted as liquefaction features due to seismic phenomena. These paleoseismic structures were dated (relative values) by measurements of cyclic annual sedimentation in the varved sediments. From these observations, we are able to establish a recurrence interval of 130 years with events for magnitude bigger than or equal to four.

Both paleoseismicity and instrumental seismicity data sets obey the Gutenberg-Richter law and the 'b' value is close to 0.86 . The fractal dimension (dimension of capacity) of spatial distribution of potentially active faults (faults oriented according to the stress tensor regime in the area) was measured by the box-counting technique $\left(D_{0}=1.73\right)$. According to the Aki empirical relation $\left(D_{0}=2 b\right)$ for the instrumental seismicity and paleoseismic data sets in the area, the fractal dimension is close to 1.72 . The similar value of the fractal dimension obtained by both techniques shows homogeneous seismic dynamics during the studied time interval. Moreover, the better established ' $b$ ' value of the paleoseismic data sets $(0.86)$ compared with the ' $b$ ' value for the incomplete historic seismicity $(<0.5)$ in the area increases the seismic series beyond the historic seismic record.
\end{abstract}

Keywords: Seismic activity; Paleoseismites; Lacustrine sediments; ‘b’ value

\section{Introduction}

One of the main goals of paleoseismological analysis is to identify recurrence intervals of earthquakes that have happened before historical chronicles. This can be realized through recognition and measurements of seismic deformational structures in sediments (seismites; Seilacher, 1969). The most usual technique is the study offaults exposed in trenches, although this methodology generally does not allow recognition of more than three or four of the most recent events. Paleoseismic analyses are particularly useful in natural

\footnotetext{
* Corresponding author. Tel.: 34-91-372-4765; fax:34-91-351-0496.

E-mail addresses: marodpas@ceu.es (M.A. Rodríguez Pascua), rbicoin@geo.ucm.es (G. De Vicente), jpcalvo@geo.ucm.es (J.P. Calvo).
}

'paleoseismographs' as, for instance, lacustrine sediments. Taking advantage of the annual character of deposition in reservoirs of the western United States, Sims (1975) dated seismites in recent laminated lacustrine sediments and correlated the deformational structures with the record of historical earthquakes in the region. Earthquake recurrence intervals in lacustrine sediments of eastern Canada were estimated by dating the deposits with radiometric techniques $\left({ }^{14} \mathrm{C}\right)$ (Doig, 1991). In a similar way, earthquake recurrence intervals have been estimated from deformational structures observed in varved sediments of an alpine glacial lake (Beck et al., 1996). Haczewski (1996) has determined the seismic signal within Oligocene pelagic limestones from the Polish Carpathians by detailed studies of the chronostratigraphy and sequence of deformational structures. In the study case by 
Haczewski (1996), the limestones exhibit varves recording annual sedimentation increments, and so these laminae couplets were used as a method of relative dating.

The lacustrine basins developed throughout the Late Miocene in the External Prebetic region, SE Spain (Fig. 1), show an exceptional sedimentary record, where abundant seismically-induced soft-sediment deformational structures occur at various sedimentary scales (Rodríguez Pascua, 1998; Rodríguez Pascua et al., 2000). Some of these deformational structures are present in laminated varve-like lacustrine sediments forming a succession up to a few hundreds of metres thick (Elízaga, 1994). Disturbed varved lamination, pseudonodules, loop bedding, 'mixed layers' and slumps (at several scales) are observed in the laminated deposits (Calvo et al., 1998; Rodríguez Pascua et al., 2000). One particular type of these seismites, the so-called 'mixedlayer structure' (Marco et al., 1994) was selected to determine the recurrence intervals of earthquakes throughout the Late Miocene. The reason for selecting mixed layers in the analysis are varied: (i) they are well preserved and abundant in the studied deposits, (ii) they cover a wide time interval, and (iii) the mixed layers give a good chance for finding a correlation with the paleoearthquake magnitude by fluidification limits calibrations.

The results obtained were integrated with the tectonic structure of the area in order to establish relationships between paleoseismic trends and recent seismic activity in the External Prebetic region.

\section{Geographic and geologic context}

The study area is located southward of the Albacete province, SE Spain (Fig. 1). This area is extended in the junction between the Iberian Chain (NW-SE trend) and the Betic Chain (SW- NE trend). During the Late Miocene, several continental basins were formed in the external zones of the Betic Chain, the so named Prebetic Zone. The Socovos-Calasparra Fault separates the Internal Prebetic Zone southward from the External Prebetic Zone. From a structural point of view the area is located in the eastern side of the Alcaraz-Hellín structural arc (Álvaro et al., 1975) (Fig. 1). In this structure, the (SW-NE) Betic trend is adapted to the Iberian trend (NW-SE) towards the west. This change in the common Betic trend coincides with a basement dextral strike-slip fault. The Mesozoic cover is affected by movements of this strike-slip fault and Keuper

diapiric intrusions form the main basal detachment (Álvaro et al., 1975; Elízaga et al., 1984).

The Alpine orogeny began during the Jurassic causing the emergence of the External Prebetic Zone during the Upper Jurassic (Malm) (Jérez Mir, 1973). The Mesozoic carbonate sediments underwent karstification and were buried by the Utrillas Formation (early Cenomanian) (Elízaga, 1994). The External Prebetic Zone remained as a shallow shelf (throughout the Late Cretaceous). During the Paleogene, the region emerged again and the sedimentation in the area was drastically reduced (Elízaga, 1994). A marine transgression covered the region throughout the middle Miocene and the earliest Late Miocene (Calvo, 1978). After the retreat of the sea, several inland lake basins were formed and they were filled up by shallow to moderate deep lacustrine deposits throughout most of the Upper Miocene (Elízaga, 1994). All the basins are located in the northern transfer zone of the Alcaraz- Hellín Arc (Fig. 1). The main structures that controlled the kinematics during the Alpine orogeny of this area were dextral strike-slip faults (NW-SE trend) that, from south to north, correspond to the Socovos-Calasparra, Lietor and Pozohondo faults (Fig. 2). The Lietor and SocovosCalasparra faults limit a high relief area, where the main lacustrine basins were developed and bounded by E-W normal faults during the Late Miocene.

The seismic structures that yield insight on the recurrence intervals of earthquakes were recognized in three of the lacustrine basins extending through the region (El Cenajo, Elche de la Sierra and Hijar basins) (Fig. 2). The sedimentary successions present in these basins, can be correlated stratigraphically (Rodríguez Pascua et al., 2000) and contain well exposed thick laminite deposits in which the paleoseismic analysis was carried out (Fig. 3).

\section{Methods and rationale}

The dating method used here to estimate recurrence intervals of paleoearthquakes is based on counting of laminite couplets, which represent annual periodic sedimentation (Glenn and Kelts, 1991; Calvo et al., 1998). In the lacustrine deposits of the External Prebetic region, the couplets are superposed dark and light millimetre-thick laminae, consisting, respectively, of diatomaceous and carbonate-rich marlstone (Calvo et al., 1998). Calculation of the number of years between successive seismic events was carried out from detailed logs. The mixed layers structures were selected as the most reliable deformational structures indicative of earthquakes in the area due to their abundance and good degree of preservation.

By studying several seismites from stratigraphic logs and outcrops, we have obtained a good series of paleoearthquakes in order to describe their size distribution. The sizes of earthquakes are distributed as a power-law according to the Gutenberg and Richter law (Gutenberg and Richter, 1956):

$$
\log N(m)=a-b m
$$

where $N(m)$ is the number of quakes with magnitude greater than $m, b$ is the ' $b$ ' value (the slope of the best fit straight line in a semi-logarithmic plot, $\log N(m)$ versus $m$ ) and $a$ is a constant. This empirical relation shows earthquakes as scale invariant phenomena. The ' $b$ ' value was obtained by using the maximum likelihood (Aki, 1965).

A test of the seismic origin of the mixed-layers would be 


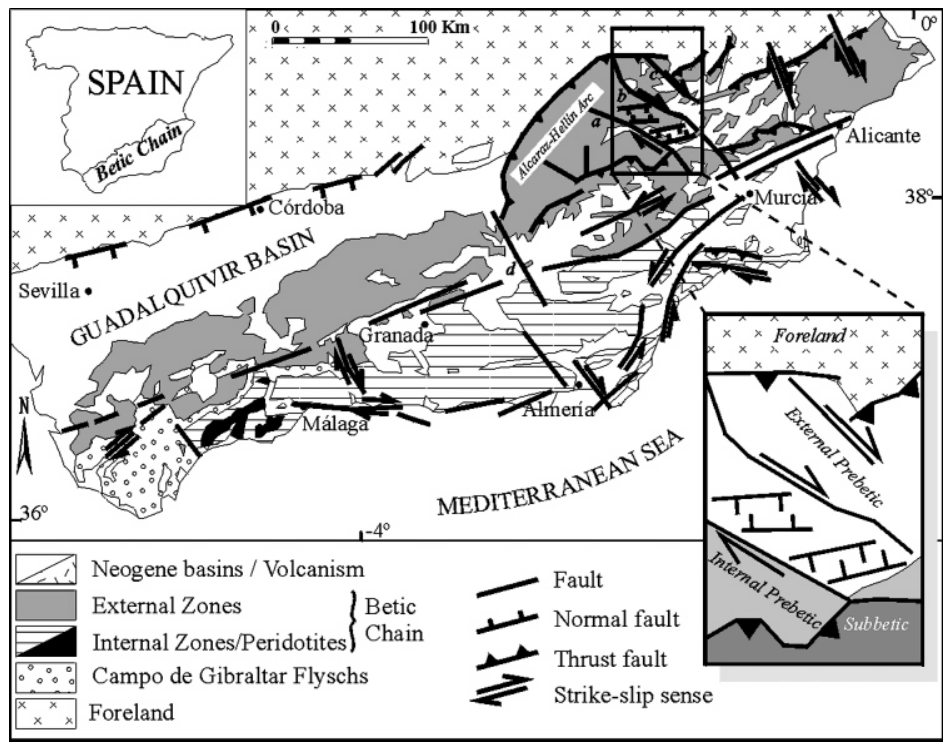

Fig. 1. Geographical and geological setting. The square represents the study area. (A) Socovos-Calasparra, (B) Lietor, (C) Pozohondo, and (D) Tiscar faults.

if the size frequency distribution associated with these structures obeys the Gutenberg-Richter law. A further step is to find the value of the ' $b$ ' value that best fits the paleoseismic data obtained from the analysis of the Late Miocene deposits and to compare this 'b' value with that recorded by instrumental measurement for recent times. The 'b’ value is a good index of the regional seismic activity in a determined tectonic area and it represents a reliable parameter to find some correlation between different temporal data sets in the area as a regionalized variable.

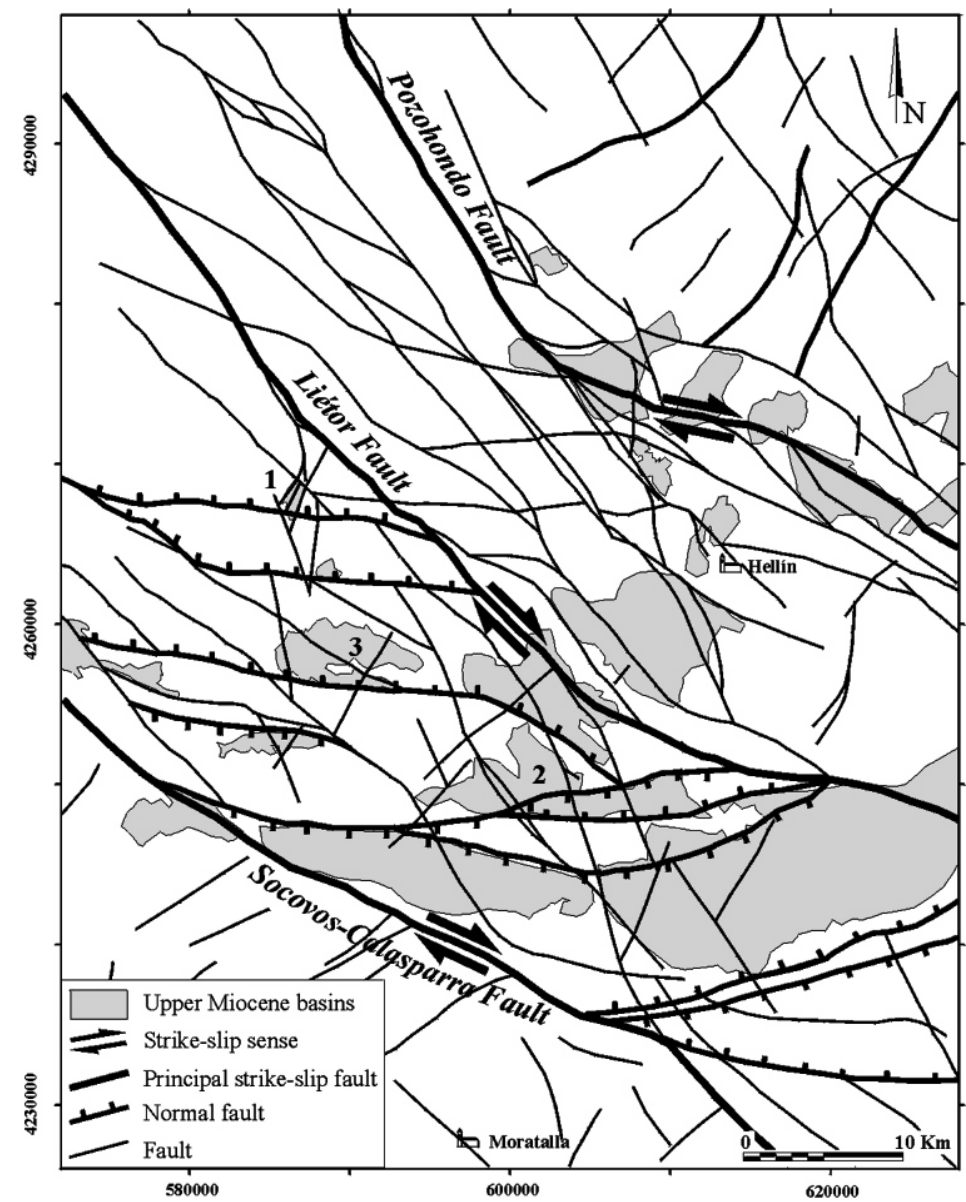

Fig. 2. Tectonic map of the study area, and lake basins (Late Miocene): (1) Híjar; (2) Cenajo; and (3) Elche de la Sierra. 30 UTM zone. 


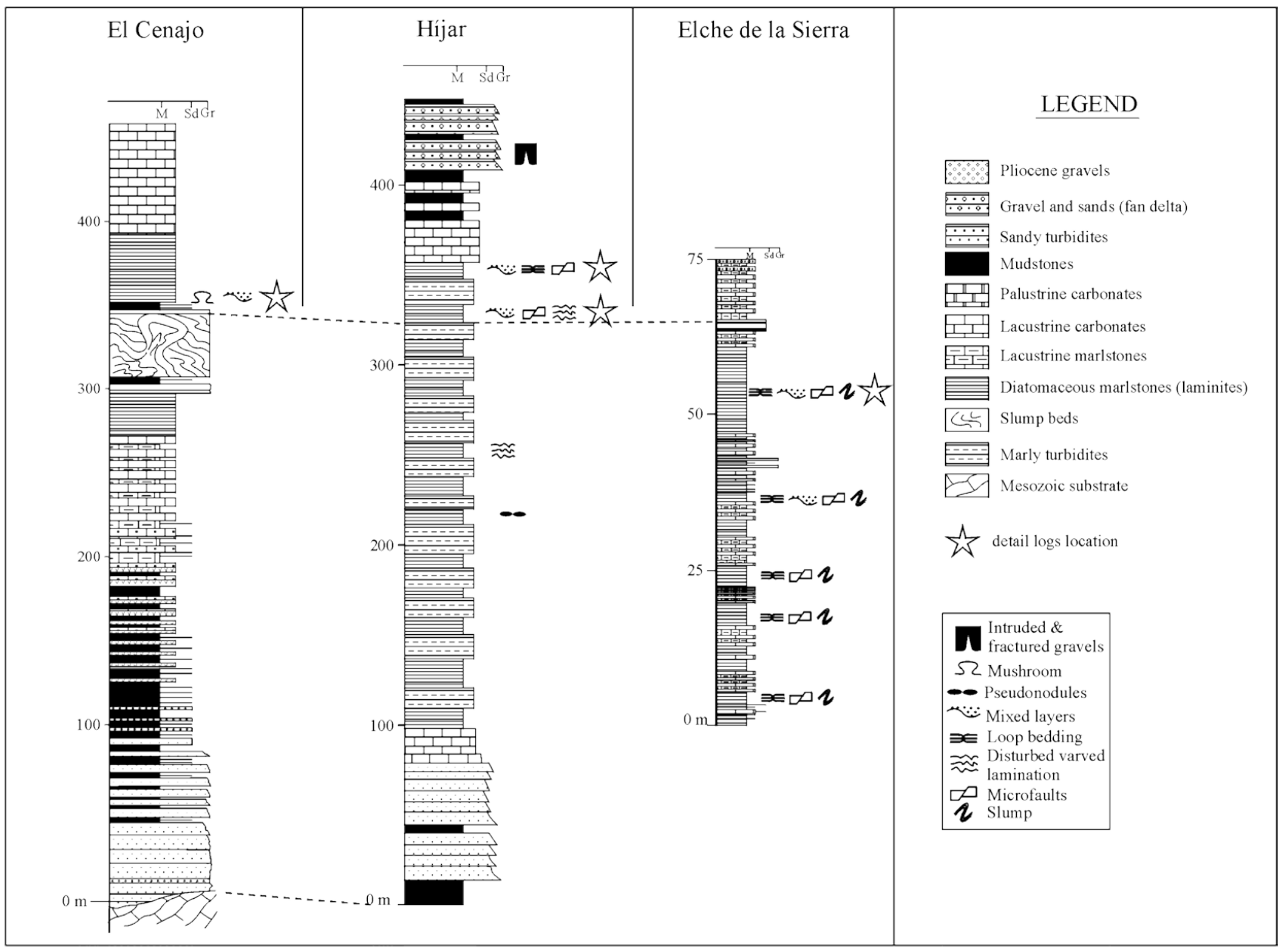

Fig. 3. Composite lithostratigraphic logs of Miocene sediments from El Cenajo, Hijar and Elche de la Sierra basins. Correlation is based on the presence of some key horizons (see text). The stratigraphic scheme records the presence of several types of seismites recognized in the lacustrine successions filling the basins. 
In this way we can characterize better the seismic phenomenon through time, increasing the seismic time series for mapping the earthquake hazard. Moreover, the relationship between the 'b' parameter and the fractal dimension (Aki, 1981; King, 1983; Hirata, 1989) allows study of the scaling rules in the same tectonic setting for a period of time beyond the instrumental records. The seismicity is a self-organized critical process in space and time (Bak and Tang, 1989). There are no space and time characteristic lengths and the frequency size-distribution is a power law with the exponent related to the fractal dimension, in this case the dimension of capacity of the spatial distribution of the earthquake faults (Aki, 1981).

\section{Mixed-layers description and interpretation}

Mixed-layers are developed only in thinly laminated sediments deposited subaqueously. These structures were first defined by Marco et al. (1994) in varved sediments of the Pleistocene Lisan Lake in the Dead Sea (Middle East). In these deposits, the mixed-layers appear associated with synsedimentary normal faults. Marco and Agnon (1995) have suggested that the mixed layers were triggered by earthquakes of magnitude equal to or greater than 5.5. These earthquakes affected the tops of the sedimentary sequences on the seafloor at the time of the event. In the lacustrine deposits studied in this work, no evidence for lateral displacement, i.e. sliding of the reworked laminites, was found (Rodríguez Pascua et al., 2000). Three zones characterized by distinctive styles of deformation can be distinguished throughout a totally developed mixed layer (Fig. 4): an uppermost fluidization zone, an intermediate zone of ductile- fragile deformation (breakage and fragmentation of varves), and a lower zone showing features typical of ductile deformation (folding of varves), this latter zone overlying non-deformed laminae.

A set of successive deformational stages can be deduced from mixed-layers (Marco and Agnon, 1995). At an initial stage, a folding band is formed at the surface of the laminated sediment (Fig. 5). As the earthquake progresses, this zone will no longer be able to accommodate the deformation by folding and it begins to fracture. The folding area goes down to an immediately lower level. The next deformational stage results in fluidization of the faulting area, the lower folding area is fragmented and the folding area progresses downwards. This way, the deformation goes down step by step from top to bottom throughout the laminate package as the earthquake progresses. However, there is a limit for the deformation to affect lower levels of the sediment, which is mainly conditioned by lithification in depth. The laminites are not affected by cyclic shear stresses when lithification is enough to prevent deformation. The more developed mixed layers observed in the studied sedimentary logs do not exceed $15 \mathrm{~cm}$ in thickness.

Fluidization is related to seismic shocks of magnitude bigger than $5-5.5$ as determined in laboratory experiments (Seed and Idriss, 1982; Atkinson, 1984; Thorson et al., 1986; Scott and Price, 1988; Audemard and De Santis, 1991; Papadopoulos and Lefkopoulos, 1993; Marco and Agnon, 1995). Therefore, accordingly, a correlation between the energy released by the earthquakes and the generated deformational structure may be established. Empirical studies carried out in Italy (Galli and Ferreli, 1995) have registered 12,880 liquefaction structures generated by 158 earthquakes (historical and instrumental). 95\% of these structures were generated within a radius lesser than $25 \mathrm{~km}$ from the epicentres of shallow earthquakes. In the External Prebetic region we have used this radius of influence as the value that determines the dimension of the area affected by liquefaction. The seismites observed were, therefore, generated near the epicentres of the earthquakes.

\section{Determination of the paleoearthquake recurrence interval}

The recurrence interval of paleoearthquakes can be determined by dating the mixed-layers observed throughout a lithological section. The relative dating is obtained by counting of laminite couplets between two successive structures. This process needs to be supplemented by the estimation of the time represented by the deformed laminae, i.e. folded, fragmented and fluidized laminae within the mixed-layer, which requires that the laminite package must be restored to its original geometry in order to determine the real recurrence interval.

Four partial lithostratigraphic logs were measured in the Late Miocene successions (Fig. 6; see location of the sections in Fig. 3). The stratigraphic log analyzed in the El Cenajo Basin is $1.54 \mathrm{~m}$ thick and consists of varve-like laminated sediments, with episodic intercalation of thin turbidite beds (less than $3 \mathrm{~cm}$ in thickness) (Fig. 6a). Some packages of laminites are locally silicified (porcelanites). The estimated sedimentation rate in the varved sediments is $0.5 \mathrm{~mm}$ /year (Calvo et al., 1998), while the rate for the silicified laminites is $0.4 \mathrm{~mm} /$ year. Twenty-one mixed layers were identified throughout the log (Fig. 6a). The time interval represented by the log is 2340 years. According to this data, the mean recurrence interval of deformational events is 111 years, with a standard deviation of \pm 82 years (Fig. $8 a$ ).

Two partial lithostratigraphic logs, mainly comprising varved beds, were measured in the Híjar Basin. One of these logs is $87 \mathrm{~cm}$ thick (log Híjar 1) (Fig. 6b). Ten welldeveloped mixed layers were identified in the log and the estimated sedimentation rate for the laminites is $0.3 \mathrm{~mm} /$ year over a time interval of 1198 years. The mean recurrence interval is 119 years (Fig. 8c), with a standard deviation of \pm 33 years. The other detailed stratigraphic log (Hijar 2) (Fig. 6c) lies $5 \mathrm{~m}$ above the underlying log. The 


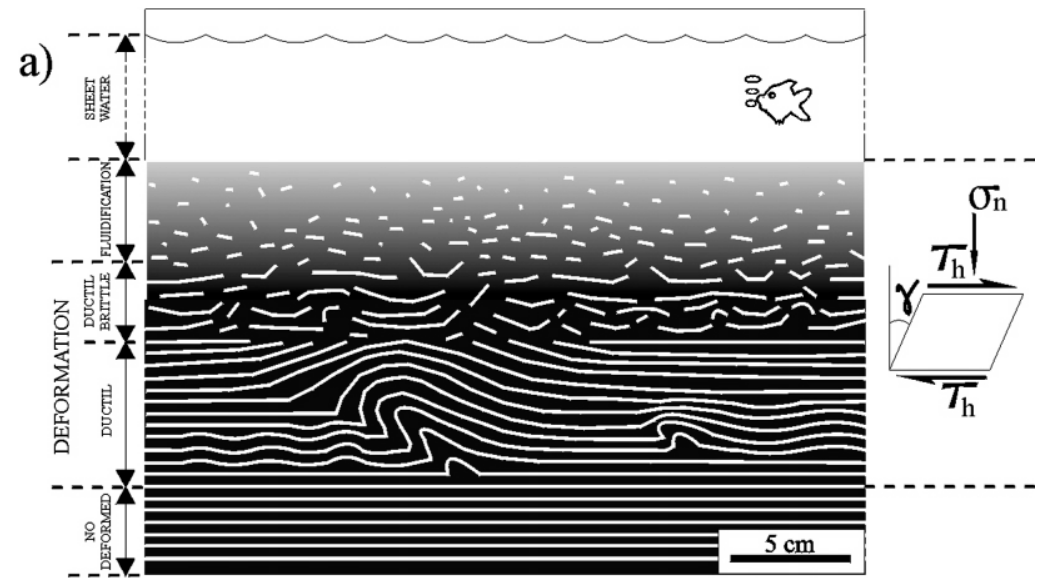

b)

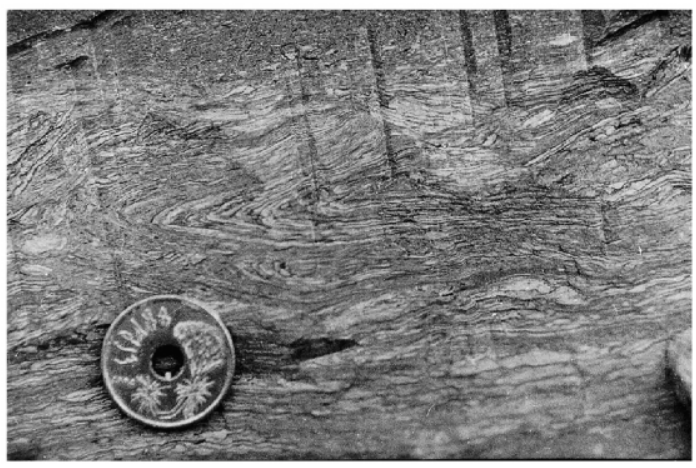

Fig. 4. Mixed layers: (a) genetic scheme $\left(s_{\mathrm{n}}=\right.$ vertical stress, $t_{\mathrm{h}}=$ cyclic tangential shear and $g=$ shear strain $)$ and (b) outcrop view.

sediments were affected by triaxial extensional stress that generated boudinage according to a 'chocolate tablet' pattern (Ramsay and Huber, 1983) or loop bedding structures (Calvo et al., 1998). These structures have been interpreted as related to creep movement on normal faults that delimit the basin (Calvo et al., 1998). Eleven mixed layers were recognized throughout the log over a time interval of 2752 years. The mean recurrence interval determined from this log is higher (250 \pm 150 years) than the underlying log (Fig. 8d). The larger standard deviation associated with this value may be related to a higher rate of aseismic creep on the boundary faults. Such creep would act to relax stresses and hence could delay the occurrence of large earthquakes.

One lithostratigraphic log has been studied in the Elche de la Sierra Basin from a borehole drilled in the diatomite deposits worked by CELITE Hispánica (Fig. 7). Thickness of the measured $\log$ is $73 \mathrm{~m}$ and the varved deposits represents 3165 years with an earthquake mean recurrence interval of 102 years ( \pm 65 years) is determined for 31 events recognized (Fig. 8b).

Although we cannot be certain that mixed-layers dated in the different logs represent independent events, the stratigraphic locations of the measured sections strongly suggest that this is in fact the case. By adding the data registered in different basins, 9446 years of total record were obtained, containing 73 dated events with a mean recurrence interval of 129 years ( \pm 98 years). The maximum interval is 454 years and the minimum interval is 23 years (Fig. 8e and Table 1).

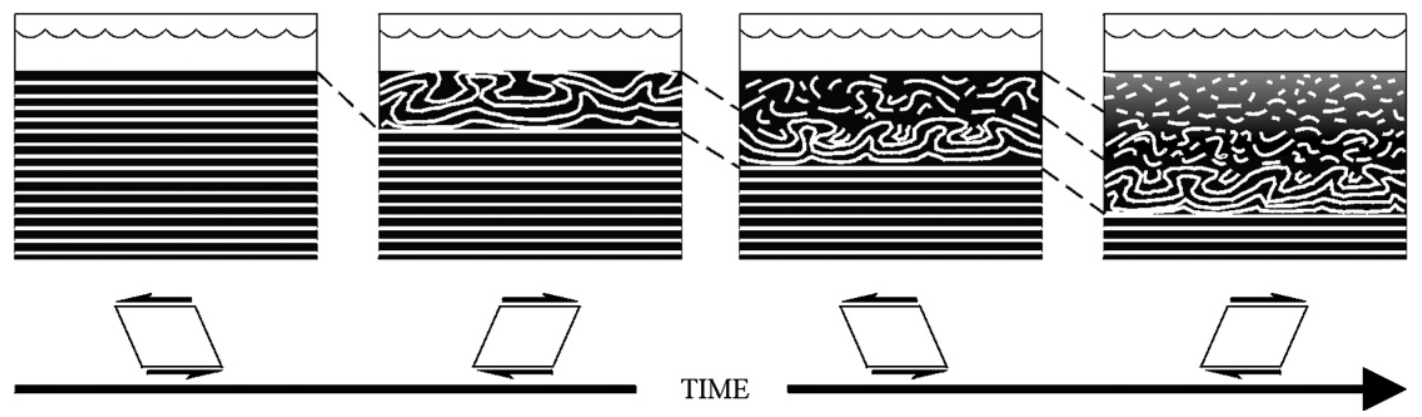

Fig. 5. Evolution of the deformation of a laminites package subjected to continuous seismic shake, resulting in a complete mixed layer structure. Cyclic shear stress throughout the duration of the earthquake is represented beneath the cartoons $\left(s_{\mathrm{n}}=\right.$ vertical stress, $t_{\mathrm{h}}=$ cyclic tangential shear and $g=$ shear strain). 


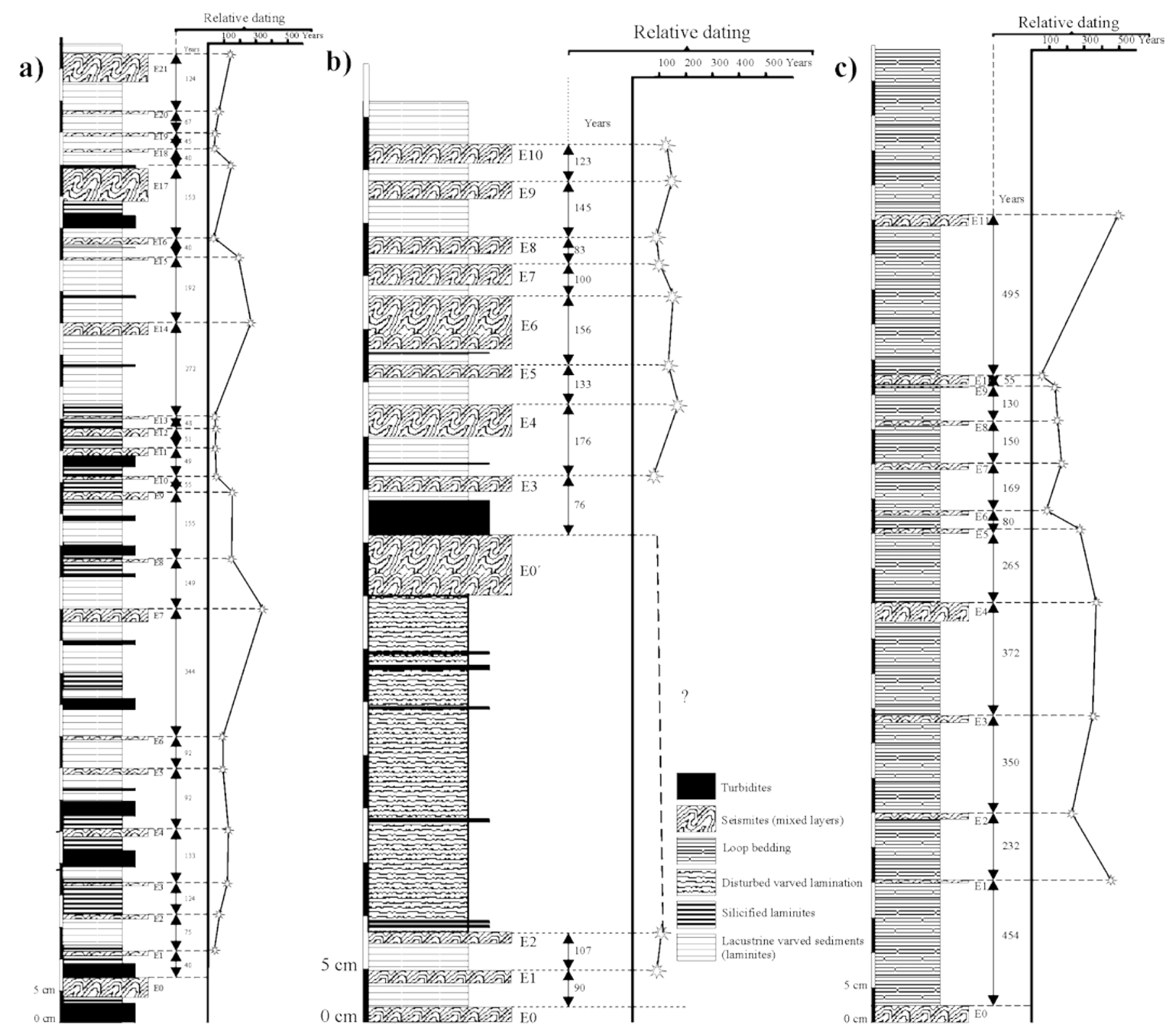

Fig. 6. Detailed stratigraphic logs from the varved beds in the El Cenajo and Híjar basins: (a) El Cenajo, (b) Híjar 1, and (c) Híjar 2. 


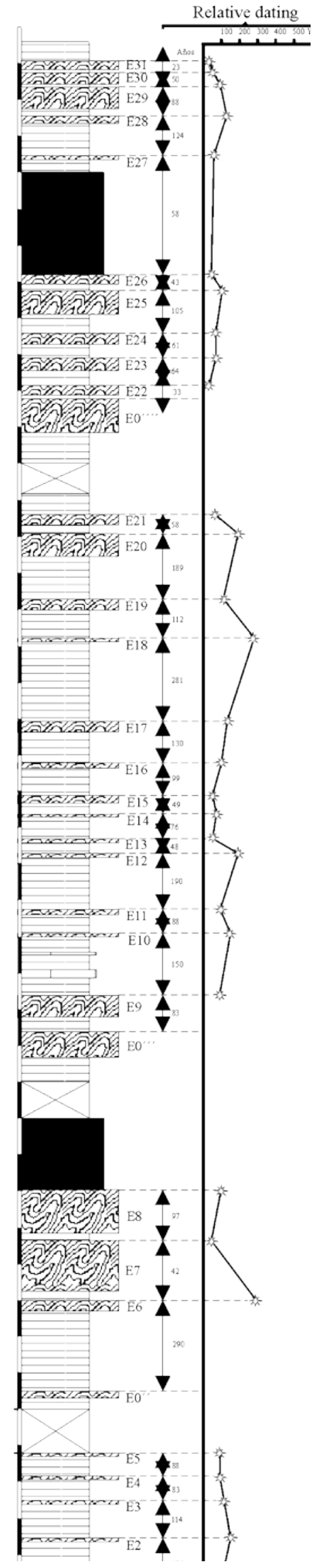

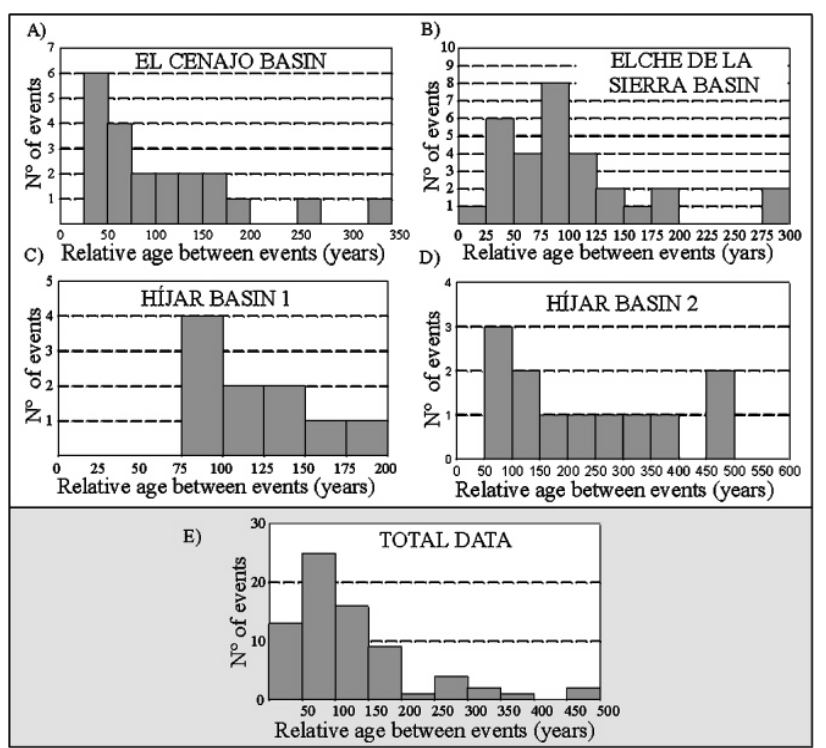

Fig. 8. Histogrmas showing frequency of relative dating ages between events (mixed layers relative dating) in the detailed logs of: (a) El Cenajo, (b) Elche de la Sierra, (c) Híjar 1, (d) Híjar 2, and (e) total data of all basins.

6. Historical and current seismicity in the study area. A 'b' value compilation

Historical seismic data in Albacete Province are very scarce. Rodríguez de la Torre (1995) describes only four historical earthquakes in Albacete for the last century (1831 - 1899). This author also carried out an inventory of earthquakes outside Albacete that affected the province. Historical earthquakes have been selected with epicentres in a radius of $120 \mathrm{~km}$ (maximum value) from the study area. This value is the distance limit for liquefaction processes triggered off by shakes of magnitude equal or bigger than eight (Moretti et al., 1995). The historical earthquake compilation in this zone is detailed in Table 2.

In some cases, the deduced intensities and the epicentral location are uncertain because the only data point is in the city (Albacete). A relationship between site and age of the historical events has not been established because the study area had a scarcity of populations for registering possible seismic events.

There are several previous works dealing with the Gutenberg-Richter law in the Betic Chain (Karnik, 1971; Hatzfield, 1978; De Miguel et al., 1983; García-Dueñas et al., 1984; Vidal et al., 1984; Sanz de Galdeano and López Casado, 1988; Buforn et al., 1988; López Casado et al., 1995; Camacho and Alonso-Chaves, 1997). These authors have calculated the ' $b$ ' value of historical and instrumental seismic data in different areas of the Betic region (Fig. 9).

The nearest work to the study area was carried out by Sanz de Galdeano and López Casado (1988). These authors

Fig. 7. Detailed stratigraphic log from the varved beds in the Elche de la Sierra basin. 
Table 1

Mixed layer dating results for the detail stratigraphic logs: Híjar, Elche de la Sierra-Cobatillas and El Cenajo

\begin{tabular}{|c|c|c|c|c|c|c|}
\hline & No. of dating events & Total registered years & $\begin{array}{l}\text { Mean recurrence } \\
\text { (years) }\end{array}$ & Standard deviation & $\begin{array}{l}\text { Minimum recurrence } \\
\text { (years) }\end{array}$ & $\begin{array}{l}\text { Maximum recurrence } \\
\text { (years) }\end{array}$ \\
\hline Cenajo 1 log & 21 & 2340 & 111 & $\wedge 82$ & 40 & 344 \\
\hline Elche S. log & 31 & 3165 & 102 & $\wedge 65$ & 23 & 290 \\
\hline Híjar 1 log & 10 & 1189 & 119 & $\wedge 33$ & 76 & 176 \\
\hline Híjar 2 log & 11 & 2752 & 250 & $\wedge 150$ & 55 & 454 \\
\hline Total data & 73 & 9446 & 129 & $\wedge 98$ & 23 & 454 \\
\hline
\end{tabular}

divide the Betic Chain into 18 areas by structural and seismic characteristics, calculating in each area the ' $b$ ' value. In the present work, for the areas within and adjacent to the study area, four are selected by these authors. The ' $b$ ' values obtained $(0.8,1.2)$ are listed in Table 3.

The average ' $b$ ' value obtained for all areas is close to one, which is also the value obtained for the whole Betic Chain. Sanz de Galdeano and Ló pez Casado (1988) explained the 'b' variations in different selected areas as due to the inclusion of many specific areas with only one seismogenic source and a poor quality of the samples.

López Casado et al. (1995) carried out a study of the 'b' value using historical (1390 - 1910) and instrumental data (1930 - 1992). They have classified the seismicity by three main criteria: local zones (Fig. 9g), regional cortical domains (Fig. 9h) and medium depth earthquakes (35 $180 \mathrm{~km}$ ) (Fig. 9i).

The low ' $b$ ' values obtained systematically from historical seismicity by López Casado et al. (1995) are a consequence of the scarce historical record for low intensity earthquakes. This means that the historical seismicity only registers events that people have felt. Small events or large earthquakes located in uninhabited areas are not registered. Also, some authors, e.g. Ló pez Casado et al. (1995), establish that the minimum limit of reliability for historical earthquakes is intensity $V$ (MKS scale) or magnitude 3.5, but the historical records of non-destructive earthquakes are rare or nil. This way, the historical accounts lack reliable data for low intensities or magnitudes. The historical seismicity is very useful, both for the search for important earthquakes and the measurements of recurrence intervals, whenever these intervals are within the time period of the historical earthquake record. Therefore, the geologic record is necessary to identify lengthy recurrence intervals or to identify low magnitude earthquakes, whenever the characteristics of the deformed sediments are sufficiently adequate for the delineation of paleoearthquakes.

The instrumental seismicity data are selected according to the detection threshold magnitude of the seismic net by IGN (Instituto Geográfico Nacional, Spain). This seismic data set (1169 data) is complete for magnitude data greater than $M=2.7$ for the time interval $1980-1995$. The selected area is located between 0 and 48 of longitude and 40 and 378 of latitude, since this way we obtain a sufficiently regional vision of the seismic phenomenon. It is necessary to recall that the laminated sediments behave as a paleoseismograph that records both local and regional seismicity. The maximum radius in which liquefaction can take place can be more than $100 \mathrm{~km}$ for earthquakes of $M>8$ (Moretti et al., 1995). The frequency size-distribution of seismic instrumental data is fixed to a power law with $b=0.86$ ( \pm 0.08$)$ (Fig. 10a).

Table 2

Compilation of historic earthquakes in $120 \mathrm{~km}$ radius around the El Cenajo basin. Data from Rodrí guez de la Torre (1995) (Mu=Murcia; V=Valencia; A = Alicante; $\mathrm{AB}=$ Albacete)

\begin{tabular}{|c|c|c|c|c|}
\hline Date & Time & Epicentre & Distance to centre of the studied area $(\mathrm{km})$ & Intensity in the studied area \\
\hline $1579-01-30$ & ? & Lorca $(\mathrm{Mu})$ & 80 & VIII \\
\hline $1674-08-10$ & ? & Lorca (Mu) & 80 & VII \\
\hline $1674-08-28$ & $10: 00$ & Lorca (Mu) & 80 & VIII \\
\hline $1748-04-23$ & $06: 45$ & Enguera (V) & 120 & $\mathrm{~V}$ \\
\hline $1818-12-20$ & 09:45 & Lorca-Totana (Mu) & 80 & VI-VII \\
\hline 21-03-29 & 18:39 & Torrevieja (A) & 110 & $\mathrm{~V}$ \\
\hline $1860-04-26$ & $08: 15$ & Albacete & 65 & V? \\
\hline 1884-11-05 & ? & El Palomar (V) & 100 & III-IV \\
\hline 1891-08-11 & $4: 00 ?$ & Almansa (Ab) & 85 & IV? \\
\hline 1899-02-29 & $21: 45$ & Minateda (Ab) & 20 & IV \\
\hline 21-03-11 & $14: 16$ & Torres de Cot. (Mu) & 70 & IV \\
\hline 03-04-11 & $11: 11$ & Lorquí (Mu) & 60 & IV \\
\hline $26-01-31$ & 03:16 & Yecla (Mu) & 70 & $\mathrm{~V}$ \\
\hline
\end{tabular}




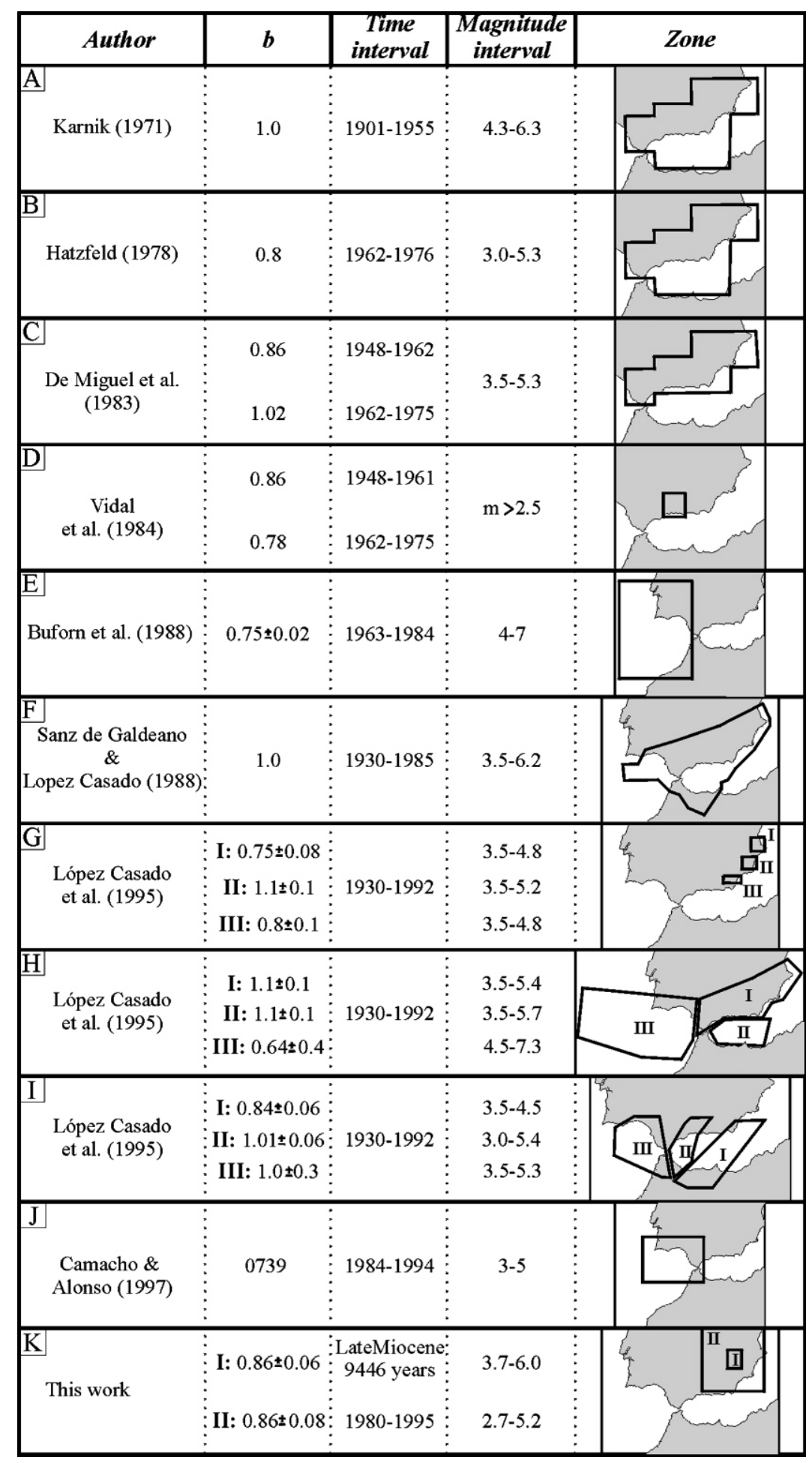

Fig. 9. Compilation of Betic Chain seismic characterizations by 'b’ value.

7. Relationship between the paleoseismicity and the current seismicity data by 'b' value

Mixed-layers in laminated beds have been used in order to obtain the 'b' value in the geologic record by building detailed logs. Since the mixed-layer thickness increases with the magnitude of deforming force that has generated them, the distribution of mixed layers obtained as the frequency of layer thickness should obey an exponential expression similar to that quoted by the Gutenberg and Richter law. The frequency size-distribution of the mixedlayers (73 events) obeys an exponential law in the Hijar, El Cenajo and Elche de la Sierra-Cobatillas basins during the Late Miocene (dated in a relative time scale). The mixed 
Table 3

The 'b' value calculated from Sanz de Galdeano and López Casado (1988) in several Betic Chain areas. Instrumental (2) corresponds to the time period between 1960 and 1992

\begin{tabular}{|c|c|c|c|c|c|}
\hline \multirow[t]{2}{*}{ Zone } & \multirow[t]{2}{*}{ Intensity } & \multirow[t]{2}{*}{ Magnitude } & \multicolumn{3}{|l|}{ Time intervals/b } \\
\hline & & & Historic & Instrumental (1) & Instrumental (2) \\
\hline Alcaraz Arc-Guadalquivir basin & $\mathrm{V}-\mathrm{IX}$ & $3.5-5.1$ & $1357-19920.3 \wedge 0.02$ & $1930-19920.85 \wedge 0.02$ & $0.86 \wedge 0.07$ \\
\hline Alcaraz Arc & V-VII & $3.5-5.0$ & 1785-1992 $0.23 \wedge 0.02$ & $1933-19940.9 \wedge 0.1$ & $1.0 \wedge 0.1$ \\
\hline Alcaraz Arc-Valencia & VI-IX & $3.5-5.8$ & $1598-19920.40 \wedge 0.08$ & $1930-19920.8 \wedge 0.1$ & $0.8^{\wedge} 0.07$ \\
\hline Segura valley & V-VII & $3.5-4.5$ & $1743-19920.4 \wedge 0.08$ & $1930-19921.2 \wedge 0.4$ & $1.3 \wedge 0.05$ \\
\hline
\end{tabular}

layer thickness has been correlated with the magnitude of the earthquake in each stratigraphic log. The 'b' value, i.e. the exponent of the exponential relationship between the frequency of layer thickness correlated with earthquake magnitudes, for our paleoseismic data is $0.86( \pm 0.06)$ (Fig. 10b). This means that the paleoseismic data series obey the Gutenberg- Richter law with a 'b' value between the commonly accepted limits (0.5 - 1.5; King, 1983), irrespective of whether the plotted variables were magnitudes or intensities of the paleoevents.

An empirical relationship between the mixed-layer thickness measured in the studied sediments and the earthquake magnitude has been established. For this purpose, we have represented the measured thicknesses of mixed-layers against earthquake magnitudes (Fig. 11a) taking in mind that the lowermost earthquake magnitude at which fluidization takes places is about five. Moreover, mixed-layers showing well-developed fluidized laminae would correspond to earthquakes of magnitude at least 5.5 (Seed and Idriss, 1982; Audemard and De Santis, 1991; Marco and Agnon, 1995). Fig. 11a shows two snapshots of a mixed layer with incipient fluidization related to magnitude five (Fig. 11b) and a mixed layer with well-developed fluidization related to magnitude 5.5 (Fig. 11c). In both cases, the geological interpretation of these structures is the

(a) Seismic intrumental data

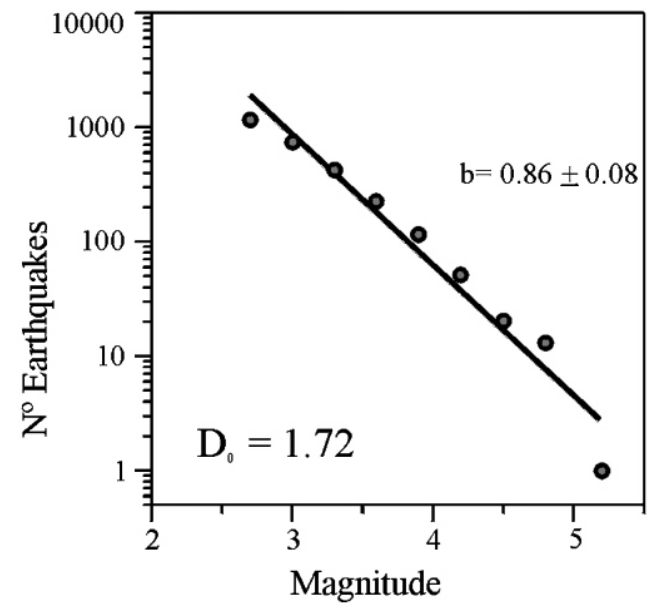

key to separate these limits. The equation of the straight line fitted in the graph may be written as follows:

$M=T / 3+3: 83$,

where $T$ is thickness of the mixed-layers and $M$ is magnitude. The constant that divides the value of $T$ must be considered as a specific value for the lake sediments studied in this work, as well as the value 3.83.

The relationship between earthquake moment magnitude and distance from the epicentre to the farthest liquefaction effect was suggested by Ambraseys (1988) and Obermeier (1996). The Ambraseys' curve could be adjusted if the causative fault can be located (Obermeier, 1996). The lacustrine basins studied are bounded by active normal faults that are located less than $25 \mathrm{~km}$ from the basins' centres. If this radius is plotted as an epicentral distance on Ambraseys' graph, liquefaction would be generated by earthquakes with a moment magnitude close to six. The estimated maximum magnitude obtained in this work from Eq. (2) is 6.1 and this value within the $25 \mathrm{~km}$ radius of liquefaction effects predicted for earthquake moment magnitudes close to six (Galli and Ferreli, 1995). Therefore, the seismic activity of the normal faults could generate the liquefaction structures in the basins.

The instrumental seismicity shows a ' $b$ ' value close to

(b) Paleoseismic total data

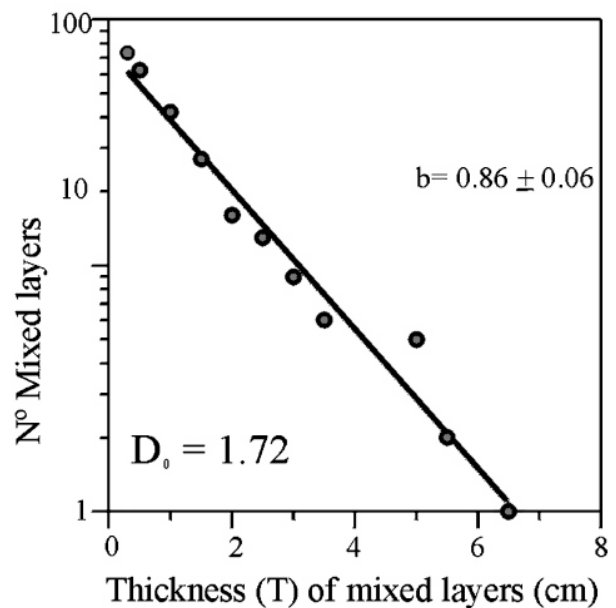

Fig. 10. Semilogarithmic graph of the cumulative frequency against magnitude, and 'b’ value: (a) seismic data (longitude: 0 to - 4 ; latitude: 37 to $40^{\circ}$ ), and (b) paleoseismic data from mixed layers located in the Híjar, El Cenajo and Elche de la Sierra basins. 
a)

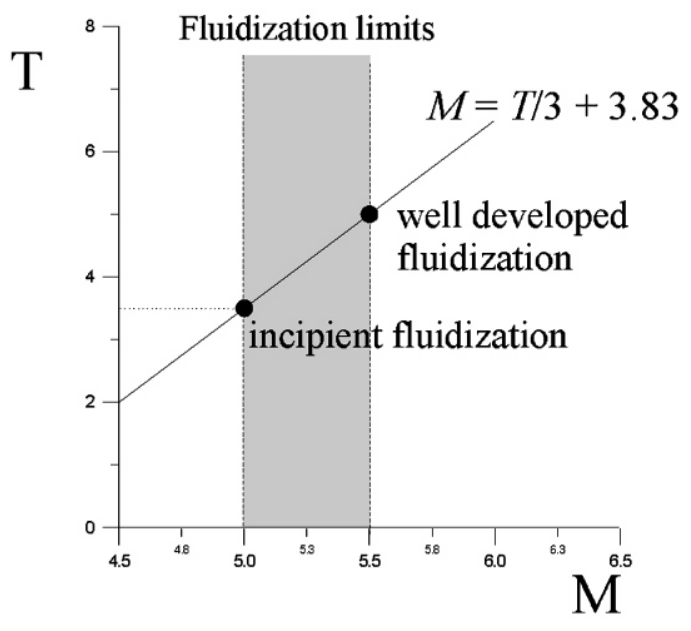

b)

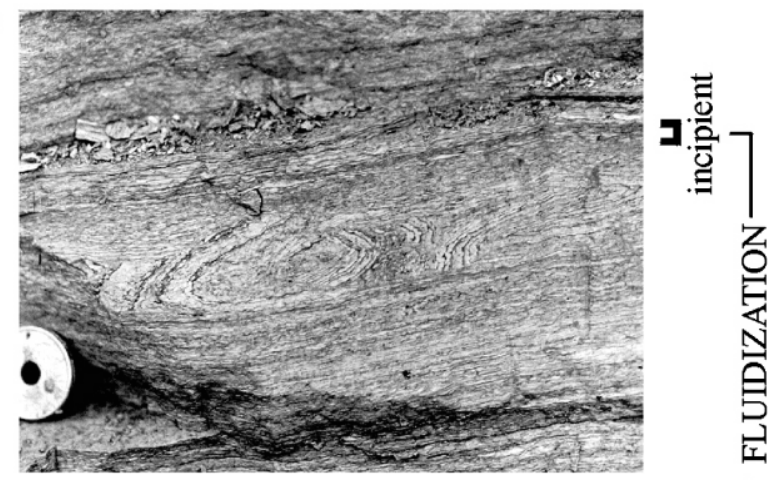

c)

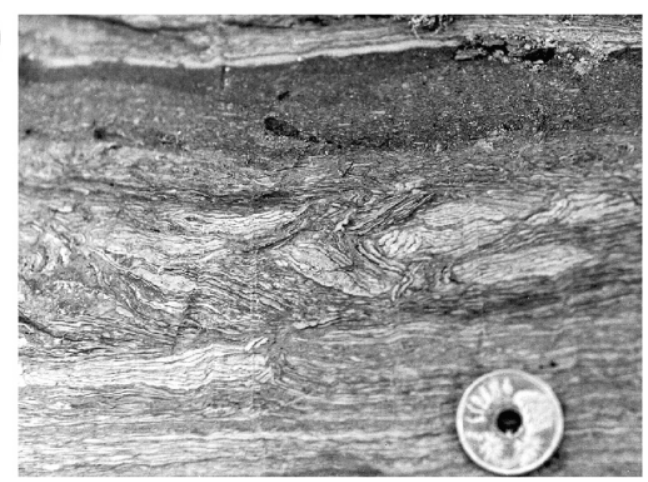

Fig. 11. (a) Lineal relationship between the thickness of mixed-layers versus earthquake magnitudes, (b) the photography represents the incipient fluidization in a mixed layer observed in the varved deposits from detailed logs, and (c) a mixed layer with a well developed fluidization level.

0.86, a value equal to that obtained after the analysis of the mixed-layer structures. This value is consistent with the fixed limits between 0.6 and 1.2 proposed for regional seismicity by Lee and Stewart (1981). These results are equivalent to those obtained by numerous authors in the Betic Chain (Karnik, 1971; Hatzfield, 1978; De Miguel et al., 1983; García-Dueñas et al., 1984; Vidal et al., 1984; Buforn et al., 1988; Sanz de Galdeano and López Casado, 1988; López Casado et al., 1995; Camacho and AlonsoChaves, 1997).

\section{Fractal analysis}

Seismicity is a self-organized critical phenomenon with spatial, temporal distribution and size-distribution as a fractal structure. This means that earthquakes are selforganized as a dynamical system evolving spontaneously in time and space towards a critical stationary stage.

In previous paragraphs we have shown that our paleoseismic data set from mixed layers measured in the Betic Chain, obeys the Gutenberg-Richter law. This means that paleoearthquakes are distributed in size as a power-law for energy released and therefore, the paleoseismic data set of the Betic Chain can be considered as a fractal self-similar data set as size distribution. Since the 'b' value obtained lies within the interval $0.5-1.5$ and is similar to the instrumental 'b' value (0.86), these data are better than the historical data set and complete the paleoseismic record throughout the last 5 Ma.

This scale-invariant distribution is associated with a specific fractal geometry of the potentially active faults. Aki (1981) found a relationship between the 'b' value and the fractal dimension (dimension of capacity or box-dimension) in the frequency size-distribution of the seismogenetic faults by the expression:

$\mathrm{D}_{0}^{*}=3 \mathrm{~b} / \mathrm{c}$,

where ' $b$ ' corresponds to the ' $b$ ' value of the GutenbergRichter relationship and $c$ is a constant close to 1.5 (Hanks and Kanamori, 1979). Eq. (3) proposed by Aki (1981) is interpreted as self-similar behaviour of the seismogenic faults, where $D_{0}^{*}$ is the fractal dimension of the spatial distribution of the seismogenetic faults (Aki, 1981; King, 1983). The range of values of this fractal dimension lies between one (Euclidean dimension of a line) and three (Euclidean dimension of a volume). If the fractal dimension ranges between one and two, the earthquakes are distributed on the interface between a line (Euclidean dimension equal to one) and a plane (Euclidean dimension equal to two). In this range, we can use a box-counting 2-D algorithm in order to compare the fractal dimension (dimension of capacity) of the spatial distribution of potentially active faults and the fractal dimension obtained from the Aki relation. Potentially active faults are defined as faults oriented according to the present stress tensor.

The potentially active fault trace map (Fig. 2) was built 


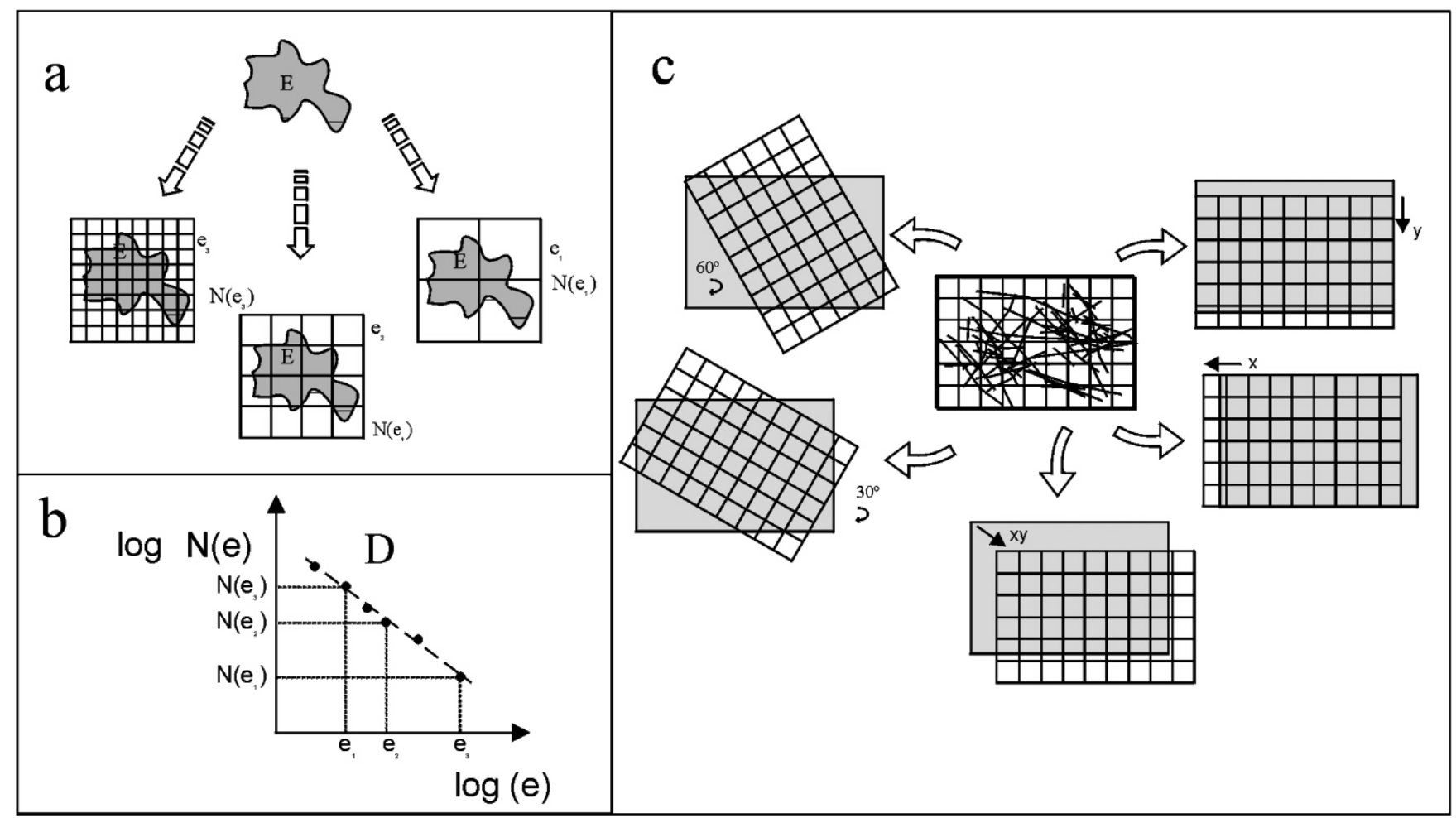

Fig. 12. (a) Box-counting technique applied in a theoretical fractal set ( $E$ ). The inner-cutoff is the minimum scale value (smallest fault size) and the outer-cutoff the maximum value (biggest non-faulted space). (b) Plotting the box number $(\mathrm{N}(e))$ that includes one part of the fractal set $(E)$ at the very least, versus the size of the box (e). $D$ is the slope of the straight fitted line. (c) Box counting lattice over a synthetic fracture set for normal, scrolled and rotated (30 and $\left.60^{\circ}\right)$ lattice.

from satellite ortho-images at 1:250,000 and 1:100,000 scales, aerial photographs at 1:33,000, 1:20,000 and 1:18,000, geological syntheses and field work in the study area. In addition, the set of potentially active faults was constrained by analysis of focal mechanisms of the recorded instrumental earthquakes (Rodríguez Pascua, 1998). The two most important fault systems are:

\section{Box-counting analysis on potentially active faults}

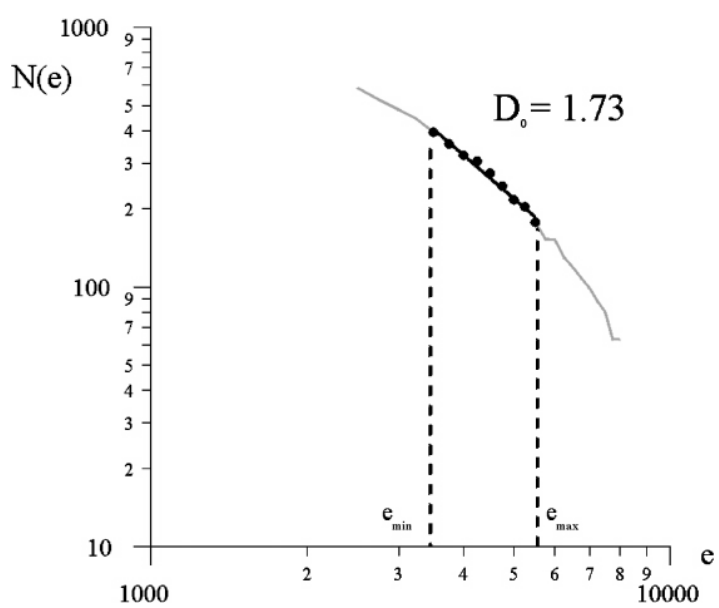

Fig. 13. Fractal dimension from box-counting analysis over the potentially active fault map in the study area. The straight curve is fitted by least squares.
1. NW-SE strike-slip faults: Socovos-Calasparra, Lietor and Pozohondo faults (Fig. 1). These faults are oriented according to the present stress field and Quaternary deposits are displaced by the faults.

2. E-W normal faults: these faults are responsible for the neotectonic activity observed in the region that caused the uplift of the Tortonian-Messinian deposits, and later resulted in development of the Tertiary lacustrine basins. The neotectonic features related to these faults are mainly represented by triangular facets cutting Quaternary deposits.

The fractal dimension was calculated for the spatial distribution of potentially active faults by a box-counting technique (Walsh and Watterson, 1993) (inverse boxcounting algorithm by DFP code; Paredes and Elorza, 1999; Pérez-López et al., 2001) (Fig. 12). The fractal dimension or dimension of capacity of the spatial distribution of faults is the degree of irregularity of fault density measured by covering the fault map with a lattice (Pérez-López et al., 2001).

This fractal dimension $\left(D_{0}\right)$ was compared with the fractal dimension measured from the ' $b$ ' values $\left(D_{0}^{*}\right)$ in two types of data set: instrumental seismicity and the frequency

size-distribution obtained from paleoseismic data from the same zone with similar geodynamics (Fig. 13). A value of $D_{0}$ (1.73) was obtained for the faults map.

The fractal dimension ( $\left.D_{0}^{*}\right)$ obtained by Eq. (1) from 'b' 
value (0.86) of paleoseismic and instrumental seismic data sets, in the Betic External Zone, showed a similar value, 1.72, compared with the fractal dimension $D_{0}$ calculated above (Fig. 10a and b). The measured fractal dimension shows a good correlation among paleoearthquakes (sizedistribution), recent earthquakes (size-distribution) and potentially active faults (spatial distribution in two dimensions) in the study area.

\section{Conclusions}

The main conclusion of this study is that there is a similarity between the magnitude-frequency distribution of earthquakes from Late Miocene paleoseismic data and present instrumental seismicity in the Betic area. The deduced magnitudes from the paleoseismicity and the instrumental seismicity data correspond to a moderate activity (low 'b' value), with mean magnitudes of 4.7 and 3.2 , respectively.

1. Earthquake recurrence intervals have been obtained by a study of mixed layers in sediments. The measurements were carried out in Late Miocene varved deposits located at the External Prebetic zone near Hellín (Albacete). This interval of 129 ( \pm 98 ) years in a total of 9446 years of records shows a mean magnitude close to four. Both the paleoseismic data and current seismicity obey the Gutenberg- Richter law for magnitude values, showing a similar ' $b$ ' value (0.86). This is not enough to claim that seismic constraints during Late Miocene and present time are the same but these paleoseismic data are better than the historical record, which shows a lower value $(<0.5)$.

2. The ' $b$ ' values obtained by several authors in different areas throughout the Betic Chain are very similar to the 'b' values calculated in this work. This indicates a good uniformity of the regional seismicity in the Betic Chain. According to this analysis, the low ' $b$ ' values obtained by different authors from historical seismicity are not due to a change in the seismic activity behaviour but the lack of records. Therefore, paleoseismic analysis from lake deposits may be an important alternative in areas with scarce historical records.

3. Paleoearthquakes recognised in lacustrine sediments are a self-organized critical phenomenon which show a fractal structure in size distribution. Fractal analysis in size distribution of paleoearthquakes and spatial distribution of faults improve the instrumental and historical seismic record in a delimited area. A similar fractal dimension, as a dimension of capacity, $D_{0}$ (1.73) by spatial fault distribution and $D_{0}^{*}(1.72)$ by the Aki relation, indicates a good relationship between instrumental seismicity and paleoseismicity data and the spatial distribution of potentially active faults in the study area. The measured fractal dimensions show a high complexity degree of spatial and frequency sizedistributions of self-similar fault sets and self-organized earthquakes generated by these faults.

\section{Acknowledgments}

Thanks are given to Dr Richard Norris and an anonymous reviewer for their helpful corrections during the review of the manuscript, improving the structure, language and focusing the main goal of this work. Special mention to Dr Armando Cisternas from EOST-Institut de Physique du Globe de Strasbourg (Universite Louis Pasteur). Financial support was by a grant of Nuclear Agency of Spain (CSN) and CICYT project AMB 940994. We thank the National Geographic Institute (IGN) of Spain for providing seismic data and Dr Juan Rueda for his helpful contribution and Dr Carlos Paredes (School of Mines of Madrid, Spain) for DFP code. This work was also partially supported by the Comunidad de Madrid.

\section{References}

Aki, K., 1965. Maximum likelihood estimate of $b$ in the formula $\log N \frac{1}{4}$ a $2 b M$ and its confidence limits. Bulletin of Earthquake Research Institute 43, 237-239.

Aki, K., 1981. A probabilistic synthesis of precursory phenomena. In: Simpson, D.W., Richards, P.G. (Eds.), Earthquake Prediction: An International Review, No. 4. Maurice Ewing Series, pp. 566-574 AGU, Washington DC.

Álvaro, M.G., Argüeso, J.M., Elízaga, E., 1975. La estructura del borde prebético de la zona de Alcaraz (Provincia de Albacete, España). Boletín Gelógico Minero 86, 467-477.

Ambraseys, N.N., 1988. Engineering seismology; earthquake engineering and structural dynamics. Journal International Association Earthquake Engineering 17, 1-105.

Atkinson, G., 1984. Simple computation of liquefaction probability for seismic hazard applications. Earthquake Spectra 1 (1), 107-123.

Audemard, A., De Santis, F., 1991. Survey of liquefaction structures induced by recent moderate earthquakes. Bulletin International Association of Engineering Geology 44, 5-16.

Bak, P., Tang, Ch., 1989. Earthquakes as a self-organized critical phenomenon. Journal of Geophysical Research 94, 15635-15637.

Beck, C., Frédéric, M., Chapron, E., Van Rensbergen, P., De Batist, M., 1996. Enhanced seismicity in the early post-glaciar period: evidence from the Post-Würm sediments of Lake Annency, north-western Alps. Journal of Geodynamics 22 (1/2), 155-171.

Buforn, E., Udías, A., Colombás, M.A., 1988. Seismicity, source mechanisms and tectonics of the Azores-Gibraltar plate boundary. Tectonophysics 152, 89-118.

Calvo, J.P., 1978. Estudios petrológico y sedimentológico del Terciario marino del sector central de la provincia de Albacete. Estudios Geológicos 34, 407-429.

Calvo, J.P., Rodríguez Pascua, M.A., Martín Velázquez, S., Ximénez, S., De Vicente, G., 1998. Microdeformation of lacustrine laminite sequences. An interpretation of loop-bedding. Sedimentology 45, 279-292.

Camacho, M.A., Alonso-Chaves, M., 1997. Sismicidad el límite de placas entre Eurasia y África al SW de Iberia, desde 1984 a 1994. Geogaceta 21, 51-54.

De Miguel, F., Vidal, F., Alguacil, G., Guirao, J.M., Olivares, G., 1983. Red 
sísmica de la Universidad de Granada. Seminario sobre Sismicidad y Riesgo Sísmico del Área Ibero-Magrebí, Córdoba, pp. 7-11.

Doig, R., 1991. Effects of strong seismic shaking in lake sediments, and earthquake recurrence interval, Temiscaming, Quebec. Canadian Journal of Earth Sciences 28, 1349-1352.

Elízaga, E., 1994. Análisis de facies y petrología de los depósitos lacustres de edad Neógeno superior de la Zona Prebética, Albacete, Istituto Estudios Albacetenses, Albacete, 216pp España.

Elízaga, E., Gallego, I.C., García, A., López. F., 1984. Hellín. Mapa Geológico de España. MAGNA 2 serie. IGME. Hoja no. 843, scale 1:50.000.

Galli, P., Ferreli, M., 1995. A methodological approach for historical liquefaction research. In: Serva, L., Slemmons, D.B. (Eds.), Perspectives in Palaeoseismology. Association of Engineering Geology 6, pp. 35-48.

García-Dueñas, V., Sanz de Galdeano, C., De Miguel, F., Vidal, F., 1984 Neotectónica y sismicidad en las Cordilleras Béticas: una revisión de resultados. Energía Nuclear (J.E.N.) 28, 231-248.

Glenn, C.R., Kelts, K., 1991. Sedimentary rhythms in lake deposits. In: Einsele, G., Ricken, W., Seilacher, A. (Eds.), Cycles and Events in Stratigraphy, Springer-Verlag, Berlin, pp. 188-221.

Gutenberg, B., Richter, C.F., 1956. Magnitude and energy of earthquakes. Annales of Geophysics 9, 1-15.

Haczewski, G., 1996. Oligocene laminated limestones as a high-resolution correlation of palaeoseismicity, Polish Carpathians. In: Kemp, A.E.S. (Ed.), Palaeoclimatology and Palaeoceanography from Laminated Sediments. Geological Society 116, 258pp.

Hanks, T.C., Kanamori, H., 1979. A moment magnitude scale. Journal of Geophysical Research 84, 2348-2350.

Hatzfield, D., 1978. Etude sismotectonique de la zone de collision IberoMaghrebine. Ph.D. thesis. University of Grenoble.

Hirata, T., 1989. A correlation between the $b$ value and the fractal dimension of earthquakes. Journal of Geophysical Research 94, $7507-7514$.

Jérez Mir, L., 1973. Geología de la zona Prebética en la transversal de Elche de la Sierra y sectores adyacentes (provs. De Albacete y Murcia). Ph.D. thesis of Universidad de Granada.

Karnik, V., 1971. Seismicity of the European Area. Part 2. D, Reidel Publishing. Company, Dordrecht.

King, G., 1983. The accommodation of large strains in the Upper Lithosphere of the Earth and other solids by self-similar fault system: the geometrical origin of $b$-value. Pure and Applied Geophysics 121 (5/6), 761-815.

Lee, W.H.K., Stewart, S.W., 1981. Principles and Applications of Microearthquake Networks, Academic Press, New York.

López Casado, C., Sanz de Galdeano, C., Delgado, J., Peinado, M.A., 1995. The $b$ value in the Betic Cordillera, Rif and nearby sectors. Relations with the tectonics of the region. Tectonophysics 248, 277-292.

Marco, S., Agnon, A., 1995. Prehistoric earthquake deformations near Masada, Dead Sea Graben. Geology 23, 695-698.

Marco, S., Agnon, A., Stein, M., Ron, H., 1994. A 50,000 years continuous record of earthquakes and surface ruptures in the Lisan Formation, the Dead Sea Graben. United States Geological Survey Open-File Report 94-568, pp. 112-114.
Moretti, M., Pieri, P., Tropeano, M., Walsh, N., 1995. Tyrrhenian seismites in Bari Area (Murge-Apulian foreland). Atti dei Convegni Licenci, 122. Terremoti in Italia. Accademia Nazionale dei Lincei, pp. 211-216.

Obermeier, S.F., 1996. Use of liquefaction-induced features for palaeoseismic analysis. An overview of how seismic liquefaction features can be distinguished from other features and how their regional distribution and properties of source sediment can be used to infer the location and strength of Holocene palaeoearthquakes. Engineering Geology 44, $1-76$.

Papadopoulos, G.A., Lefkopoulos, G., 1993. Magnitude- distance relations for liquefactions in soil from earthquakes. Bulletin Seismological Society of America 83 (3), 925-938.

Paredes, C., Elorza, F.J., 1999. Fractal and multifractal analysis of fractured geological media: surface- subsurface correlation. Computer \& Geosciences 25, 1081-1096.

Pérez-López, R., Muñoz-Martín, A., Paredes, C., De Vicente, G., Elorza, F.J., 2001. Dimensión Fractal de la Distribución Espacial de Fracturas en el área granítica de El Berrocal (Sistema Central): Relación con el tensor de esfuerzos. Revista de la Sociedad Geológica de España 13 (3-4) (in Spanish).

Ramsay, J.G., Huber, M.I., 1983. The Techniques of Modern Structural Geology. Volume 1: Strain Analysis, Academic Press, London.

Rodríguez de la Torre, F., 1995. Los terremotos de la Provincia de Albacete, Instituto de Estudios Albacetenses, Albacete, (in Spanish).

Rodríguez Pascua, M.A., 1998. Paleosismicidad y sismotectónica de las cuencas lacustres neógenas del Prebético de Albacete. Ph.D. of Universidad Complutense de Madrid (in Spanish).

Rodríguez Pascua, M.A., Calvo, J.P., De Vicente, G., Gómez Gras, D., 2000. Seismites in lacustrine sediments of the Prebetic Zone, SE Spain, and their use as indicators of earthquake magnitudes during the Late Miocene. Sedimentary Geology 135 (1-4), 117-135.

Sanz de Galdeano, C., López Casado, C., 1988. Fuentes sísmicas en el ámbito Bético-Rifeño. Revista de Geofísica 44, 175-198.(in Spanish).

Scott, B., Price, S., 1988. Earthquake-induced structures in young sediments. Tectonophysics 147, 165-170.

Seed, H.B., Idriss, I.M., 1982. Ground Motions and Soil Liquefaction during Earthquakes, Earthquake Engineering Research Institute, Berkeley.

Seilacher, A., 1969. Fault graded beds interpreted as seismites. Sedimentology 13, 155-159.

Sims, J.D., 1975. Determining earthquake recurrence intervals from deformational structures in young lacustrine sediments. Tectonophysics 29, 141-152.

Thorson, R.M., Claiton, W.S., Seever, L., 1986. Geologic evidence for a large prehistorical earthquake in eastern of Connecticut. Geology 14, 463-467.

Vidal, F., De Miguel, F., Sanz de Galdeano, C., 1984. Neotectónica y sismicidad en la Depresión de Granada. Energía Nuclear (J.E.N.) 28 (149-150), 267-275.(in Spanish).

Walsh, J.J., Watterson, J., 1993. Fractal analysis of fracture patterns using the standard box-counting technique: valid and invalid methodologies. Journal of Structural Geology 15 (12), 1509-1512. 